\title{
PENGARUH LAMA FERMENTASI TERHADAP RANCIDITAS MINYAK KELAPA YANG DIPRODUKSI SECARA TRADISIONAL
}

\author{
Paulus Valentino Patty \\ Alumni Prongram Studi Pendidikan Biologi \\ E-mail: falen_patty@yahoo.com
}

\begin{abstract}
Background: People of Maluku has the habit to cultivate oil palm fruit into oil by fermentation. The fermentation process that traditionally takes place at varying fermentation makes it easier rancid oil. This study aims to determine whether there was an effect on the fermentation time ranciditas coconut oil traditionally produced, ranciditas measured using a peroxide.

Methods: The study was conducted at the Laboratory of Basic Chemistry Pattimura University in Ambon on 10 September 2014 with a long fermentation 0 hours (control), 6 hours, 12 hours, 18 hours, 24 hours, and analyzed using descriptive analysis.

Results: There is a very real effect ranciditas level lower palm oil contained in the fermentation 6 hours with an average rate of 0.0988 peroxide.

Conclusion: Long fermentation influence on ranciditas coconut oil traditionally produced. The impact that an increase in peroxide value is the average with increasing length of fermentation.
\end{abstract}

Keywords: Ranciditas, Long Fermentation, Coconut Oil

\begin{abstract}
Abstrak
Latar Belakang: Masyarakat Maluku mempunyai kebiasaan untuk mengolah buah kelapa menjadi minyak kelapa dengan cara fermentasi. Proses fermentasi yang berlangsung secara tradisional dengan lama fermentasi yang bervariasi membuat minyak lebih mudah tengik. Penelitian ini bertujuan untuk mengetahui apakah ada pengaruh lama fermentasi terhadap ranciditas minyak kelapa yang diproduksi secara tradisional, ranciditas diukur menggunakan bilangan peroksida.

Metode: Penelitian dilakukan di Laboratorium Kimia Dasar Universitas Pattimura Ambon pada tanggal 10 September 2014 dengan lama fermetasi 0 jam (kontrol), 6 jam, 12 jam, 18 jam, 24 jam, dan dianalisis menggunakan analisis deskriptif.

Hasil: Terdapat engaruh yang sangat nyata yaitu tingkat ranciditas minyak kelapa yang rendah terdapat pada lama fermentasi 6 jam dengan rata-rata angka peroksida 0,0988.

Kesimpulan: Lama fermentasi sangat berpengaruh terhadap ranciditas minyak kelapa yang diproduksi secara tradisional. Pengaruh yang terjadi yaitu adanya peningkatan angka peroksida rata-rata seiring dengan bertambahnya lama fermentasi.
\end{abstract}

Kata Kunci: ranciditas, lama fermentasi, minyak kelapa. 


\section{PENAHULUAN}

Kepulauan Maluku terdiri dari hamparan pulau-pulau dengan garis pantai yang panjang merupakan daerah yang baik bagi pertumbuhan tanaman kelapa. Tanaman kelapa (Cocos nucifera) mendapat julukan pohon kehidupan, karena mulai dari akar, batang, daun, bunga dan buah dapat di manfaatkan untuk memenuhi sebagian besar kebutuhan manusia. Bagi masyarakat maluku kelapa merupakan salah satu komoditas terpenting dan merupakan sumber pendapatan yang dapat diandalkan dari pemanfaatan tanah pekarangan (Warisno, 2003).

Salah satu produk kelapa adalah minyak kelapa. Minyak kelapa di buat dari daging buah kelapa yang diolah. Daging buah kelapa kaya akan kandungan lemak, karbohidrat, protein, dan vitamin. Jumlah protein terbesar terkandung dalam daging buah (endosperm) kelapa yang setengah tua, sedangkan kandungan kalori dan lemak mencapai maksimal pada buah kelapa tua (Heyana, dkk, 2000).

Minyak kelapa memiliki sejumlah fungsi yang dapat dimanfaatkan dalam kehidupan manusia. Disamping sebagai bahan pangan yang penting dalam penggorengan, minyak kelapa juga baik digunakan untuk meningkatkan kesehatan masyarakat. Maka tidak heran minyak kelapa selalu menjadi incaran banyak orang. Selain itu minyak juga merupakan sumber energi dimana satu gram minyak dapat menghasilkan 9 kkal (Winarno, 2004).

Meskipun penggunaan minyak kelapa yang diolah secara modern sejauh ini masih aman bagi kesehatan namun sebagian masyarakat Maluku terutama yang berdomosili didaerah pedesaan masih tergantung pada minyak yang diolah secara tradisional karena mudah dilakukan serta tidak memerlukan banyak biaya. Disamping alasan ekonomi karena harga minyak kelapa yang diolah secara modern memiliki harga lebih mahal, tindakan ini juga untuk memanfaatkan buah kelapa yang bertumpuk dan sulit dipasarkan pada waktu musim panen. Minyak mengandung asam lemak tak jenuh dan beberapa asam lemak esensial seperti asam oleat, linoleat dan linolenat (Sulistyo et al, 2006).

Pembuatan minyak kelapa dengan fermentasi merupakan salah satu alternatif untuk mengatasi masalah pada pembuatan dengan cara tradisional. Beberapa faktor mempengaruhi produksi minyak kelapa secara fermentasi diantaranya $\mathrm{pH}$, konsentrasi inokulum, suhu, bahan baku kelapa, dan lamanya fermentasi. Sehingga perlu dilakukan pengkajian untuk mendapatkan kondisi optimal proses sehingga dihasilkan jumlah dan kualitas minyak kelapa yang lebih optimal. Selain itu dalam proses pembuatan minyak kelapa secara fermentasi minyak yang dihasilkan lebih banyak dan warnanya lebih jernih (Sukmadi dan Nugroho, 2002).

Pembuatan minyak kelapa dengan fermentasi lebih kurang di diamkan selama beberapa jam. Selama proses fermentasi berlangsung terjadi suksesi (pergantian) mikroba dalam emulsi santan dan terjadi perubahan keasaman $(\mathrm{pH})$. Perubahan $\mathrm{pH}$ merupakan salah satu faktor yang mempercepat oksidasi minyak. Oksidasi minyak adalah reaksi asam-asam lemak tidak jenuh yang menyusun lemak sebagai radikal bebas dengan molekul oksigen sehingga menyebabkan minyak menjadi lebih cepat tengik dan menyebabkan penurunanan kualitas minyak kelapa, Winarno (2004).

Menurut ketaren (2008), ada tiga penyebab ketengikan dalam lemak yaitu ketengikan oleh oksidasi, (oxidative ranciditas), ketengikan oleh enzim (enzymatic ranciditas), dan ketengikan oleh proses hidrolisa (hidrolitic ranciditas). Ketengikan oleh oksidasi terjadi karena proses oksidasi oleh oksigen udara terhadap asam lemak tidak jenuh dalam lemak. Proses oksidasi dapat terjadi pada suhu kamar, dan selama proses pengolahan menggunakan suhu tinggi. Hasil oksidasi lemak dalam bahan pangan tidak hanya mengakibatkan rasa dan bau tidak enak, tetapi juga dapat menurunkan nilai gizi, karena kerusakan vitamin (karoten dan tokofenol) dan asam lemak esensial dalam lemak.

Kerusakan lemak yang utama adalah timbulnya bau dan rasa tengik yang disebut proses ketengikan. Hal ini disebabkan oleh otooksidasi radikal asam lemak tidak jenuh dalam lemak. Radikal bebas dengan $\mathrm{O} 2$ membentuk peroksida aktif yang dapat membentuk hidroperoksida yang bersifat tidak stabil dan mudah pecah menjadi 
senyawa dengan rantai karbon yang lebih pendek oleh radiasi energi tinggi, energi panas, katalis logam, atau enzim. Senyawasenyawa dengan rantai $\mathrm{C}$ lebih pendek ini adalah asam-asam lemak, aldehidaaldehida, dan keton yang bersifat volatile dan menimbulkan bau tengik pada lemak (Winarno, 2004).

Mutu dari suatu minyak dapat diketahui dari rasa dan aromanya. Salah satunva adalah ketengikan atau adanya Asam Peroksida. Peroksida merupakan suatu tanda adanya pemecahan atau kerusakan pada minvak karena terjadi oksidasi (kontak dengan udara) yang menyebabkan bau aroma tengik pada minyak. Ukuran dari ketengikan dapat diketahui dengan menentukan bilangan peroksida. Semakin tinggi bilangan peroksida maka semakin tinggi pula tingkat ketengikan suatu minyak (ASA, 2000).

\section{METODE}

\section{Prosedur Penelitian}

Pengambilan Sampel dilakukan sebagai berikut:

a. Sebanyak $10 \mathrm{~kg}$ kelapa parut, dilarutkan dalam $10 \mathrm{~L}$ air dengan perbandingan $1: 1$.

b. Penambahan air dilakukan secara bertahap sebanyak $3 x$ yaitu $3 \mathrm{~L}$, 4L dan $3 \mathrm{~L}$.

c. Setelah penambahan air kelapa parut diperas sehingga diperoleh santan.

d. Santan yang diperoleh ditempatkan dalam wadah, kemudian di diamkan selama interval waktu 6 jam, 12 jam, 18 jam, dan 24 jam, dalam kondisi tertutup rapat, tujuanya agar tidak ada oksigen yang masuk.

e. Setelah didiamkan selama 6 jam, akan terjadi pemisahan skim pada bagian bawah dan krim pada bagian atas.

f. Setelah itu krim diangkat dan dipanaskan selama 15 menit sampai airnya menguap dan proteinnya menggumpal, gumpalan protein ini disebut blondo.

g. Blondo yang mengapung diatas minyak kemudian disaring 2-3 kali. h. Minyak dikemas dengan botol kaca.

i. Lakukan prosedur yang sama pada santan yang didiamkan selama 12, 18, dan 24 jam. Untuk perlakuan control, minyak kelapa dimasak tanpa didiamkan.

1. Pengukuran Derajat Ketengikan (Bilangan peroksida).

a. Minyak kelapa ditimbang seberat $5 \mathrm{gr}$ dalam labu Erlenmeyer kemudian dimasukkan $30 \mathrm{ml}$ campuran pelarut yang terdiri dari $60 \%$ asam asetat glacial dan $40 \%$ kloroform.

b. Setelah itu ditambahkan 0,5 ml larutan kalium iodida jenuh sambil dikocok.

c. Setelah 2 menit setelah penambahan kalium iodida, ditambahkan $30 \mathrm{ml}$ akuades.

d. Kelebihan lod dititrat dengan larutan natrium thiosulfat $\left(\mathrm{Na}_{2} \mathrm{~S}_{2} \mathrm{O}_{3}\right) 0,1 \mathrm{~N}$.

e. Dengan cara yang sama, dibuat juga penentuan blanko. Titrasi blanko tidak boleh lebih dri $0,1 \mathrm{ml}$ larutan natrium thiosulfat.

f. Hasil pengukuran dinyatakan dalam milimol per 1000 gram

$$
\begin{aligned}
& \text { Milimol/1000 gram } \\
& \qquad=\frac{0,5 \times \mathrm{A} \times \mathrm{N} \times 1000}{\mathrm{G}}
\end{aligned}
$$

Dimana:

A: Jumlah ml larutan natrium thiosulfae.

$\mathrm{N}$ : Normalitas larutan natrium thiosulfat.

G: Berat lemak (gram) (Ketaren, 2008).

Rancangan penelitian yang digunakan dalam penelitian ini yaitu menggunakan Rancangan Acak Kelompok Pola Nonfaktorial dengan 4 waktu lama fermentasi, seperti terlihat pada Tabel 4.1. Sebagai pembanding, maka digunakan minyak kelapa tanpa fermentasi (0 jam) sebagai kontrol.

\section{HASIL DAN PEMBAHASAN \\ Hasil \\ Diskripsi Hasil Penelitian}

Hasil penelitian angka peroksida minyak kelapa fermentasi yang diproduksi secara tradisional dapat dilihat pada Tabel 1 sebagai berikut: 
Tabel 1. Hasil Pengukuran Angka Peroksida Pada Sampel Minyak Kelapa Fermentasi Yang Diproduksi Secara Tradisional.

\begin{tabular}{cccccc}
\hline \multirow{2}{*}{ Perlakuan } & \multicolumn{3}{c}{ Ulangan } & \multirow{2}{*}{ Total } & \multirow{2}{*}{ Rata-Rata (\%) } \\
\cline { 2 - 4 } & $\mathbf{U}_{\mathbf{1}}$ & $\mathbf{U}_{\mathbf{2}}$ & $\mathbf{U}_{\mathbf{3}}$ & & 0,232 \\
$\mathrm{~L}_{0}$ & 0,1993 & 0,2494 & 0,2473 & 0,696 & 0,0988 \\
$\mathrm{~L}_{1}$ & 0,0987 & 0,0980 & 0,0997 & 0,2964 & 0,3494 \\
$\mathrm{~L}_{2}$ & 0,3493 & 0,3490 & 0,3499 & 1,0482 & 0,4799 \\
$\mathrm{~L}_{3}$ & 0,4493 & 0,4969 & 0,4937 & 1,4399 & 0,5630 \\
$\mathrm{~L}_{4}$ & 0,4953 & 0,5976 & 0,5962 & 1,6891 & \\
\hline
\end{tabular}

Keterangan: $L_{0}=$ Kontrol

$\mathrm{L}_{1}=$ Lama fermentasi 6 jam

$\mathrm{L}_{2}=$ Lama fermentasi 12 jam

$\mathrm{L}_{3}=$ Lama fermentasi 18 jam

$\mathrm{L}_{4}=$ Lama fermentasi 24 jam

Dari Tabel 1 menunjukan hasil pengukuran angka peroksida pada sampel minyak kelapa fermentasi yang diproduksi secara tradisional dengan 3 kali pengulangan memiliki bilangan peroksida yang berbeda-beda pada setiap pengulangannya. Berdasarkan Tabel 1 terlihat bahwa angka peroksida minyak kelapa fermentasi yang diproduksi secara tradisional dengan lama fermentasi 0 jam (kontrol) yaitu $0,232 \%$, lama fermentasi 6 jam yaitu 0,0988\%, lama fermentasi 12 jam yaitu $0,3494 \%$, lama fermentasi 18 jam yaitu $0,4799 \%$, lama fermentasi 24 jam yaitu $0,5630 \%$.

Untuk selengkapnya dapat dilihat perbandingan angka peroksida rata-rata minyak kelapa fermentasi yang diproduksi secara tradisional pada Grafik 1 sebagai berikut:

\section{Angka Peroksida}

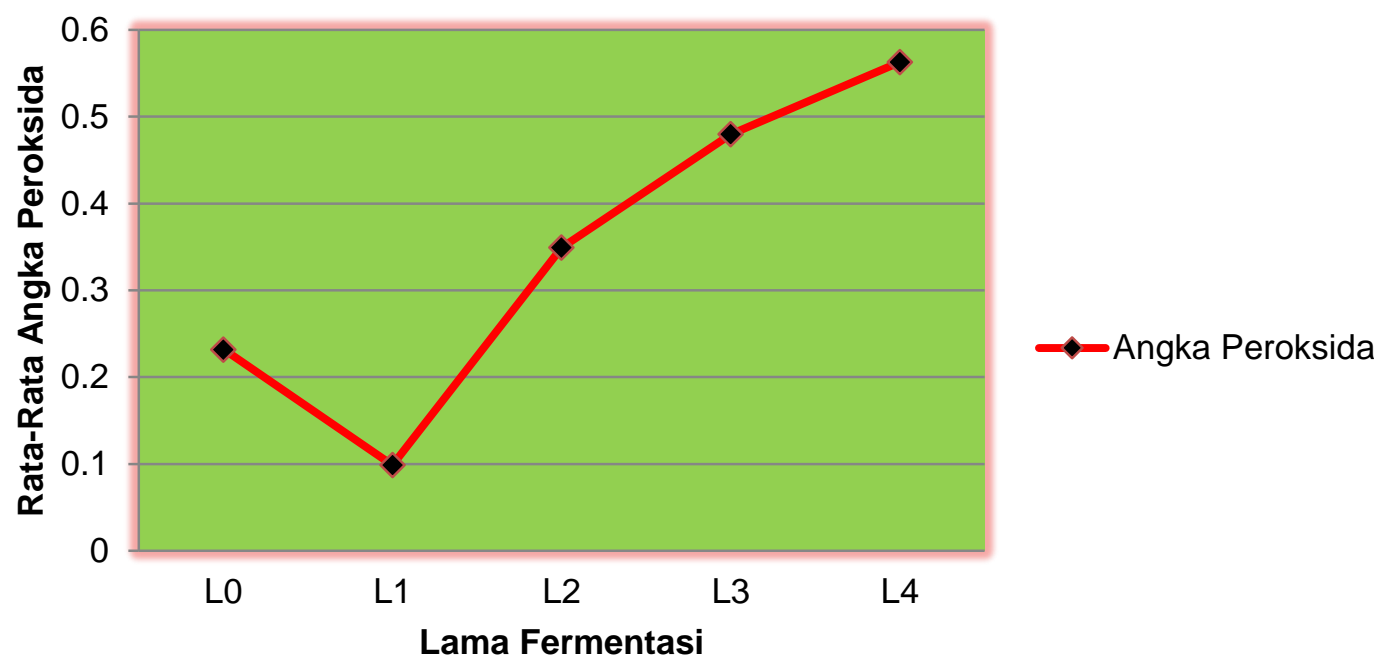

\section{Grafik 1. Rata-rata Presentase Angka Peroksida Pada Kontrol dan Keempat Lama Fermentasi.}

\section{Pembahasan}

Hasil penelitian menunjukan bahwa pada setiap tindakan perlakuan semakin lama fermentasi maka angka peroksida minyak kelapa semakin meningkat. Analisis angka peroksida digunakan untuk menentukan tingkat kerusakan oksidasi minyak. Kerusakan oksidasi minyak 
berlangsung apabila terjadi kontak antara sejumlah oksigen dengan ikatan rangkap pada minyak.

Dari penelitian yang dilakukan, dapat diketahui bahwa angka peroksida yang paling rendah terdapat pada lama fermentasi 6 jam yaitu 0,0988\%. Hal ini disebabkan kerena asam lemak tidak jenuh yang terdapat dalam minyak kelapa fermentasi 6 jam relatif lebih kecil. Sifat dan daya tahan minyak terhadap kerusakan sangat tergantung pada komponen penyusunnya, terutama kandungan asam lemak. Minyak yang mengandung asam lemak tidak jenuh cenderung mudah teroksidasi, sedangkan yang banyak mengandung asam lemak jenuh lebih mudah terhidrolisis. Asam lemak pada umumnya bersifat semakin reaktif terhadap oksigen (Alamsyah, 2005).

Pada perlakuan kontrol angka peroksidanya lebih besar dari perlakuan lama fermentasi 6 jam, hal ini disebabkan karena perlakuan kontrol merupakan proses pembuatan minyak kelapa dengan cara tradisional. Proses pembuatan minyak kelapa dengan cara tradisional, minyak lebih mudah tengik karena kadar air masih sangat tinggi. Menurut Gunawan dkk, (2003), dengan adanya kadar air maka rantai karbon dalam minyak terputus, rantai karbon yang terputus akan berikatan dengan oksigen sehingga peroksida minyak bertambah.

Ketaren (2008) juga mengemukakan bahwa sejumlah air dalam lemak dapat menjadi medium yang baik bagi pertumbuhan jamur yang dapat menghasilkan enzim peroksida. Enzim peroksida dapat mengoksidasi asam lemak tidak jenuh sehingga terbentuk peroksida, disamping itu juga dapat mengoksidasi asam lemak jenuh pada ikatan karbon atom sehingga membentuk asam keton dan akhirnya metil keton. Dengan adanya air, minyak dapat terhidrolisis menjadi gliserol dan asam lemak. Reaksi ini dapat dipercepat dengan adanya basa, asam, dan enzimenzim. Hidrolisis dapat menurunkan mutu minyak (Winarno, 2002). Kandungan air dalam minyak mampu mempecepat kerusakan minyak.

Pada lama fermentasi 18 jam angka peroksidanya yaitu $0,5630 \%$, atau lebih tinggi dari kontrol $0,232 \%$, dan lama fermentasi 12 jam yang angka peroksidanya hanya $0,3494 \%$, tetapi lama fermentasi 18 jam memiliki angka peroksida yang lebih rendah dari lama fermentasi 24 jam.

Pada lama fermentasi 24 jam angka peroksida minyak kelapa meningkat dan lebih tinggi dari semua perlakuan. Ini disebabkan karena semakin lama waktu fermentasi maka asam lemak tidak jenuh yang terdapat dalam minyak kelapa akan semakin besar dan membuat minyak dapat berkontak langsung dengan oksigen, dengan demikian reaksi pembentukan radikal bebas yang selanjutnya diubah menjadi hidroperoksida akan semakin meningkat. Hal ini didukung oleh pendapat Winarno (2002), bahwa reaksi oksidasi minyak dimulai dengan pembentukan radikal-radikal bebas yang disebabkan oleh faktor-faktor yang dapat mempercepat reaksi seperti cahaya, energi panas, katalis logam dan enzim. Radikal bebas dengan oksigen akan membentuk peroksida aktif yang dapat membentuk hidroperoksida yang bersifat sangat tidak stabil.

Menurut Jamieson (1943), hasil yang terbentuk pada kerusakan minyak atau lemak antara lain adalah campuran aldehid, keton, asam-asam hidroksi serta asam lemak bebas dengan berat molekul rendah, yang menyebabkan timbulnya bau tengik dan rasa getir yang tidak dikehendaki pada minyak. Kandungan asam lemak tidak jenuh yang tinggi dapat menyebabkan kerusakan pada minyak dan menimbulkan penyakit. Asam lemak bebas sudah terdapat di dalam minyak atau lemak sejak bahan tersebut mulai dipanen dan jumlahnya akan terus bertambah selama proses pengolahan dan penyimpanan, Hartley (1976).

Semakin lama waktu fermentasi maka kondisi $\mathrm{pH}$ akan kembali menjauhi $\mathrm{pH}$ titik isoelektrik sehingga protein kembali melarut. Dengan larutnya kembali protein, maka muatan protein akan berpengaruh terhadap kerusakan minyak. Menurut Ketaren (2008) bila minyak atau lemak bebas dari kotoran berupa protein maka mikroba berpengaruh kecil terhadap perubahan kualitas minyak selama penyimpanan. Kerusakan pada minyak berupa ketengikan yang menyebabkan bau dan rasa yang tidak enak pada minyak. Kerusakan pada minyak tidak hanya mengakibatkan rasa dan bau tidak enak, tetapi juga dapat menurunkan nilai gizi, karena kerusakan vitamin (karoten dan 
tokofenol) dan asam lemak esensial dalam lemak.

Asam lemak tidak jenuh dapat mengikat oksigen pada ikatan rangkapnya, sehingga membentuk peroksida. Adanya peroksida dalam jangka waktu lama akan mengakibatkan distruksi vitamin yang terkandung dalam minyak. Ketaren, (2008) mengemukakan bahwa semakin tinggi bilangan peroksida, maka minyak akan lebih mudah tengik, peroksida dapat mengakibatkan distruksi beberapa vitamin (misalnya vitamin $A, C, D, E, K$ dan sejumlah kecil vitamin B). Peroksida juga dapat mempercepat proses timbulnya bau tengik dan flavour yang tidak dikehendaki pada minyak. Jika jumlah peroksida dalam bahan pangan (lebih besar dari 100) akan bersifat sangat beracun dan tidak dapat dimakan, disamping minyak tersebut mempunyai bau yang tidak enak. Peroksida akan membentuk persenyawaan lipoperoksida secara nonenzimatis dalam otot usus dan mitokondria. Lipoperoksida dalam aliran darah mengakibatkan denaturasi lipoprotein yang mempunyai kerapatan rendah. Jika lipoprotein mengalami denaturasi, akan mengakibatkan deposisi lemak dalam pembuluh darah (aorta) sehingga menimbulkan gejala atherosclerosis.

\section{KESIMPULAN}

Berdasarkan hasil penelitian yang dilakukan dapat disimpulkan bahwa lama fermentasi sangat berpengaruh terhadap ranciditas minyak kelapa yang diproduksi secara tradisional. Pengaruh yang terjadi yaitu adanya peningkatan angka peroksida rata-rata seiring dengan bertambahnya lama fermentasi. Hasil pengukuran angka peroksida minyak kelapa fermentasi menunjukan rata-rata angka peroksida pada kontrol (tanpa fermentasi) adalah 0,232, untuk lama fermentasi 6 jam adalah 0,0988, untuk lama fermentasi 12 jam adalah 0,3494, untuk lama fermentasi 18 jam adalah 0,4799 , untuk lama fermentasi 24 jam adalah 0,5630. Dengan demikian Ratarata Angka Peroksida yang terendah terdapat pada lama fermentasi 6 jam yaitu 0,0988 .

\section{DAFTAR PUSTAKA}

Alamsyah, Andi Nur. 2005. Virgin Coconut Oil Minyak Penakluk Aneka Penyakit. Jakarta: Agro Media Pustaka.

Anwar C, (1996). Pengantar Praktikum Kimia Organik. Jakarta: Departemen Pendidikan dan Kebudayaan, DIKTI.

Barlina R, 2004. Pasca Panen Kelapa. Jurnal Penelitian Kelapa Vol.7 No.2 Thn.1994. Balai Penelitian Kelapa, Manado.

Cahyono dan Lia, U. 2009. Proses Pembuatan Virgin Coconut Oil (VCO) Dengan Fermentasi Menggunakan Starter Ragi Tempe. Jurusan Teknik Kimia, Fak. Teknik, Universitas Diponegoro.

Decker, E.A., 2002, "Antioxidant Mechanism", In: Akoh. C.C. and D.B. Min, Editor: Food Lipids, Chemistry, Nutrition and Biotecnology, Marcel Dekker, Inc. New York.

Halliwell, B. and J.M.C. Gutteridge. 1999. Free Radicals in Biology and Medicine. 3th Ed. Oxford University Press, Inc., New York.

Hartley, 1976. The Oil Palm. Longmans. London

Heyana. N, J. Towaha, Wahyudi, danWagyono, 2000. Pembuatan Minyak Kelapa Secara Fermentasi. Makalah Pelatihan Instruktur Penerapan Teknologi Perkebunan Provinsi Riau. Tgl. 22 November 2000.

Jamieson, GS. 1943. Vegetable fat and Oils $2^{\text {nd }}$ ed. Reinhold Publishing Corporation. New York.

Karouw. S, Rindengan. B, dan P.M. Pasang, 2002. Manfaat minyak kelapa untuk kesehatan. Buletin Palma. Pusat Penelitian dan Pengembangan Perkebunan. Bogor.

Ketaren, S. 2008. Pengantar Teknologi Minyak dan Lemak Pangan. Jakarta: Universitas Indonesia Press.

Langseth, L. 2000. Antioxidants and Their Effect on Health. Aspen Publishers, Inc. Gaithersburg, Maryland.

Lee, J., N. Koo, and D.B. Min. 2004. Reactive oxygen species, aging, and antioxidative nutraceuticals. Compre Rev. in Food Sci. and Food Safety.

Muchtadi, D. 2012. Pangan Fungsional dan Senyawa Bioaktif. Bandung: Alfabeta. 
Price, M. 2004. Terapi Minyak Kelapa. Prestasi Pustaka, Jakarta.

Setiaji, B. dan Prayugo, S. 2006. Membuat VCO Berkualitas Tinggi. Depok: Penebar Swadaya.

Subiyantoro, 2003. Kajian Proses Pemucatan Minyak Goreng Bekas dengan Metode Adsorpsi dan Pengkelatan. Skripsi. Departemen Teknologi Industri Pertanian, FatetaIPB, Bogor.

Sudarmadji, S, Haryono, B, dan Suhardi. 1989. Analisa Bahan Makanan dan Pertanian. Liberty, Yogyakarta.

Sukartin, KJ., dan Sitanggang, M., 2005. Gempur Penyakit dengan VCO, Penebar Swadaya, Jakarta.

Sukmadi B. dan Nugroho NB. 2002. Kajian Penggunaan Inokulum pada Produksi Minyak Kelapa Secara Fermentasi.
Jurnal Biosains dan Bioteknologi Indonesia, Vol.2. No.1. 12-17.

Sulistyo, Saputro, et al, 2006. Kinetic Studies on the Reduction of Trace $\mathrm{Cr}$ (VI) in Natural Water by Flow InjectionSolid Phase Spectrometry.43 ${ }^{\text {rd }}$ Joint Meeting of the 8 Kyushu Branches of Chemical Societies, July 82006 , Kitakyushu, Japan.

Sutarmi dan Rozaline, H., 2005. Taklukkan Penyakit dengan VCO, Penebar Swadaya, Jakarta.

Thieme, J. G., 1968, Coconut Oil Processing FAO Agri Culture Development Paper, Rome.

Warisno, 2003, "Budi Daya Kelapa Genjah", Kanisius, Yogyakarta.

Winarno, F.G. 2004.Kimia Pangandan Gizi. Jakarta: Gramedia Pustaka Utama. 